\title{
IMPLEMENTASI METODE CONSTANT PERCENT OF SALARY DALAM PENENTUAN IURAN DANA PENSIUN SYARIAH BAGI PEDAGANG UMKM
}

\author{
Mohamad Andri Ibrahim \\ Universitas Islam Bandung Jalan Ranggading No 8 Bandung Indonesia \\ Andri.ibrahim@gmail.com
}

\begin{abstract}
Abstrak
Tujuan penelitian iniuntuk mengetahui berapa iuran yang harus dipenuhi dalam rangka mengahadapi masa tuanya bagi pedagang UKM dengan menggunakan metode Contant Percent Of Salary. Dana pensiun saat ini merupakan sebuah kebutuhan bagi sebagian masyarakat Indonesia, sebuah penelitian yang dilakukan oleh HSBC baru-baru ini mengatakan bahwa 1 dari 3 masyarakat Indonesia belum siap menghadapi masa tua, hal ini diakibatkan oleh kurangnya persiapan sebagian masyarakat dalam mempersiapkan hari tua terutama bagi kalangan pedagang kecil, PKL, Petani dan Nelayan. Maka dengan itu perlu pengkajian tentang dana pensiun syari'ah yang merupakan solusi bagi kalangan masyarakat tertentu. Dana pensiun syari'ah mempunyai prinsip ta'awun yang berarti saling tolong menolong.
\end{abstract}

\section{Kata Kunci : Dana Pensiun Syari'ah, Contant Percent Of Salary}

\section{Abstract}

The purpose of this study is to find out what contributions must be fulfilled in order to deal with the old age for SME traders using the Contant Percent Of Salary method. Pension funds are currently a necessity for some Indonesians, a study conducted by HSBC recently said that 1 in 3 Indonesian people are not ready to face old age, this is caused by a lack of preparation of some people in preparing for old age especially for the community small traders, street vendors, farmers and fishermen. Therefore, it is necessary to study the syari'ah pension fund which is a solution for certain communities. Syari'ah pension fund has ta'awun principle which means help each other.

Keywords: Pension Fund of the shari'a, Contant Percent Of Salary

\section{PENDAHULUAN}

\section{A. Latar Belakang Masalah}

Saat ini masyarakat masih mengira bahwa dana pensiun hanya bisa dinikmati oleh para PNS, TNI/POLRI, atau pegawai swasta. Masyarakat belum terlalu mengenal istilah dana pensiun untuk kalangan pedagang di pasar, PKL, petani ataupun nelayan. Akibatnya kita masih

Received: 2016-09-16 | Reviced: 2017-01-27 | Accepted: 2017-01-31

Indexed : DOAJ, Garuda, Crossref, Google Scholar | DOI: https://doi.org/10.29313/amwaluna.v1i1.1997 
sering melihat para lansia yang harusnya beristirahat menikmati hari tua, dipaksa untuk tetap berjualan dan mengundang rasa iba setiap orang yang melihat, atau tmereka tetap pergi ke ladang menjadi buruh tani meskipun fisik sudah tidak sanggup. Hal demikian mereka lakukan karena tuntutan agar kehidupan mereka tetap dapat berlangsung sebagaimana mestinya. (Emilisa, 2001) Dari fenomena di atas, maka perlu adanya suatu kajian supaya semua elemen profesi yang ada di Indonesia sadar pentingnya dana pensiun untuk kehidupan hari tua.

Pada perkembangan zaman modern saat ini, asuransi merupakan sebuah kebutuhan pokok. Salah satu model asuransi yang ditawarkan adalah menggunakan asuransi syariah yang merupakan solusi alternatif bagi masyarakat dalam memilih produk asuransi. Asuransi syariah merupakan sebuah fitur bisnis dalam ekonomi syariah yang dapat dimanfaatkan umat untuk menjawab kebutuhan ekonominya. (Sumanto, 2009) Di dalam asuransi syariah terdapat fitur-fitur produk yang dapat bersaing dengan asuransi konvensional. Selanjutnya, asuransi menjadi sebuah pertimbangan sebagai salah satu ikhtiar perencanaan keuangan sekaligus upaya menghilangkan, menghindarkan, bahkan memperkecil resiko yang mungkin terjadi di kemudian hari. (Sumanto, 2009)

Semua manfaat dari asuransi akan lebih bermakna jika menggunakan prinsip syariah apalagi potensi asuransi syariah di Indonesia sangat tinggi mengingat Indonesia merupakan negara dengan penduduk muslim terbesar di dunia. (Ramadhani, 2015)Terdapat beberapa kelebihan asuransi syariah, diantaranya: (Sumanto, 2009)

- Adanya landasan tauhid,

- Adanya keadilan,

- Adanya kasih sayang,

- Bertolong menolong,

- Bersikap jujur dan terpercaya,

- Bersikap Ridha,

- Tanpa sogok (Risywah),

- Tanpa curang (Tathfif),

- Tanpa Gharar, Maisir, dan Riba

- Maslahat,

- Melayani.

Salah satu produk yang ditawarkan oleh asuransi syariah adalah asuransi dana pensiun yang merupakan dana asuransi yang digunakan untuk menikmati hari tua yang dapat diambil dari hasil manfaat asuransi dan investasi yang dilakukan. Dana pensiun syariah mempresentasikan hadits Nabi yang menjadi dasar konsep 
dana pensiun syariah, yaitu konsep tolongmenolong atau saling melindungi dalam kebenaran. (Sula, 2004)

Dana Pensiun Syariah merupakan sebuah alternatif pilihan dalam memberikan jaminan kesejahteraan bagi para pekerja atau pedangang kecil di Indonesia, jaminan tersebut dapat dimungkinkan dalam memberikan penyelesaian masalah bagi para pekerja dan pedagang kecil berupa jaminan hari tua, atau jaminan kecelakaan yang mengakibatkan cacat fisik yang memungkinkannya tidak bekerja lagi. Resiko tersebut tentu akan memberikan dampak ekonomi bagi dirinya maupun keluarganya yang akan mengganggu kelangsungan hidupnya. Maka diciptakanlah sebuah program yang dapat memberikan manfaat bagi dirinya sebagai proteksi diri dalam menghadapi resikoresiko tersebut. (Haryanti, 2013)

Program dana pensiun syariah masih dilaksanakan secara terbatas oleh DPLK (Dana Pensiun Lembaga Keuangan) yang dilaksanakan di beberapa Bank syariah dan Asuransi Syariah. Umumnya dana pensiun syariah akan ditawarkan oleh DPLK berupa produk pensiun dengan konsep tabungan dan produk pensiun plus asuransi jiwa.

Program dana pensiun yang dilakukan oleh DPLK di beberapa Bank
Syariah dan Asuransi Syariah membantu para pedagang dalam meningkatkan profitabilitasnya. Potensi dana pensiun syariah ini sangat besar, mengingat lembaga keuangan syariah di Indonesia terus tumbuh dan mendekati lembaga keuangan konvensional. Potensi tersebut tentunya perlu dukungan dari pemerintah terutama OJK sebagai otoritas dalam pembuatan peraturan yang dapat meningkatkan perhimpunan dana masyarakat sebagai peserta dana pensiun syariah

Dalam paper ini akan disajikan suatu rumusan tentang dana pensiun syariah dengan menggunakan teori aktuaria, dimana objek penelitian dilakukan terhadap beberapa pedagang pasar tradisional.

\section{B. Rumusan Masalah.}

Dari latar belakang masalah di atas, dapat dirumuskan rumusan masalah dalam penelitian ini, yaitu: (1)Bagaimana konsep dana pensiun diterapkan di lembaga keuangan syari'ah untuk para pelaku UMKM? (2)Bagaimana perhitungan penentuan iuran dana pensiun syari'ah dengan menggunakan fungsi aktuaria pada metode Constant Percent Of Salary bagi para pelaku UMKM?

\section{Tujuan Penelitian}


Mohamad Andri Ibrahim, Implementasi Metode Constant Percent Of Salary Dalam....

1. Untuk mengetahui bagaimana konsep dana pensiun syari'ah apabila diterapkan di lembaga keuangan syari'ah apabila diterapkan untuk para pelaku UMKM.

2. Mengetahui cara perhitungan penentuan iuran dana pensiun dengan menggunakan fungsi aktuaria pada metode Constant Percent Of Salary bagi para pelaku UMKM.

\section{Metode Penelitian.}

Metode penelitian yang digunakan adalah experimen yaitu dengan menggunakan studi kasus dengan menggunakan data asumsi penulis yang diolah secara kuantitatif dengan menggunakan fungsi-fungsi aktuaria yaitu menggunakan fungsi yang digunakan untuk perhitungan iuran normal dan kewajiban aktuaria. Fungsi dasar aktuaria yang digunakan antara lain fungsi survival komposi, fungsi tingkat bunga, fungsi pendapatan, fungsi manfaat dan fungsi anuitas. Berikut ini beberapa penjelasan dari masing-masing fungsi tersebut. (Winklevoss, 1992)

\section{PEMBAHASAN}

Pengertian pensiun adalah hak seseorang untuk memperoleh penghasilan setelah bekerja sekian tahun dan sudah memasuki usia pensiun atau ada sebabsebab lain sesuai dengan perjanjian yang telah ditetapkan. Penghasilan dalam hal ini biasanya diberikan dalam bentuk uang dan besarnya tergantung dari peraturan yang ditetapkan. (Wahab, 2001)

Menurut Undang-Undang Nomor 11 tahun 1992 tentang Dana Pensiun bahwa Dana Pensiun adalah badan hukum yang mengelola dan menjalankan program yang menjanjikan manfaat pensiun. Dengan demikian, jelas bahwa yang mengelola dana pensiun adalah perusahaan yang memiliki badan hukum seperti bank umum atau asuransi jiwa.

Menurut (Elvira \& Linawati, 2014) bahwa dana pensiun adalah yang secara khusus dihimpun dengan tujuan untuk memberikan manfaat kepada peserta ketika mencapai usia pensiun, mengalami cacat, atau meninggal dunia. Program dana pensiun adalah dana yang dibentuk untuk pembayaran karyawan setelah tidak bekerja lagi karena memasuki masa pensiun. Dengan adanya dana pensiun karyawan peserta kelak akan tetap memperoleh jumlah penghasilan tertentu, sekalipun sudah tidak bekerja lagi.

Adapun (Scott, 2004) mendefinisikan bahwa pensiun funds is a financial institution that controls assets and 
disburses income to people after they have retired from gainful employment. Menurut (Perry, 1983) bahwa pensiun fund is an investment maintened by companies and other employers to pay the annual sum required under the business or organization's pensiun scheme.

Sedangkan (Meicaecaria, 2007) mengartikan bahwa dana pensiun adalah badan hukum yang mengelola dan menjalankan program yang menjanjikan manfaat pensiun bagi pesertanya. Badan hukum tersebut secara rutin mengumpulkan iuran pensiun dari pegawai yang menjadi pesertanya, kemudian membayarnya kembali pada saat pegawai tersebut sudah tidak bekerja lagi (pensiun).

Dana pensiun dapat diartikan juga sebagai dana yang sengaja dihimpun secara khusus dengan tujuan untuk memberikan manfaat kepada karyawan pada saat mencapai usia pensiun, meninggal dunia atau cacat. Dana yang terhimpun dikelola dalam suatu lembaga yang disebut trust sedangkan pengelolaannya disebut trustee atau dapat juga dilakukan oleh perusahaan asuransi atau badan lain yang dibentuk secara khusus untuk mengelola dana tersebut. (Veithzal, Rivai. \& dkk, 2007) Oleh karena itu, dana pensiun ini bukan hanya bersifat melindungi kekayaan nasabah tapi menjamin kontinuitas penghasilan dan kesejahteraan sewaktu nasabah tidak produktif lagi (Muhammad).

Sementara (Soemitra, 2009) mengartikan bahwa, dana pensiun adalah hak seseorang untuk memperoleh penghasilan setelah bekerja sekian tahun dan sudah memasuki usia pensiun ada sebab-sebab lain sesuai dengan perjanjian yang telah ditetapkan. Sedangkan dana pensiun syariah adalah dana pensiun yang dikelola dan dijalankan berdasarkan prinsip syariah. Pertumbuhan lembaga keuangan syariah di Indonesia secara perlahan mendorong perkembangan dana pensiun yang beroperasi sesuai dengan prinsip syariah. Sampai saat ini, dana pensiun syariah berkembang pada Dana Pensiun Lembaga Keuangan (DPLK) yang dilaksanakan oleh beberapa bank dan asuransi syariah.

Pengertian perusahaan dana pensiun secara umum dapat dikatakan meruapakan perusahaan yang memungut dana dari karyawan suatu perusahaan dan memberikan pendapatan kepada peserta pensiun sesuai perjanjian. Artinya dana pensiun dikelola oleh suatu lembaga dan memungut dana dari pendapatan para karyawan suatu perusahaan, kemudian membayarkan kembali dana tersebut dalam bentuk pensiun setelah jangka waktu tertentu sesuai dengan perjanjian antara kedua belah pihak. Pengertian 
Mohamad Andri Ibrahim, Implementasi Metode Constant Percent Of Salary Dalam....

sesuai dengan perjanjian artinya pensiun dapat diberikan pada saat karyawan tersebut sudah memasuki usia pensiun atau ada sebab-sebab lain sehingga memperoleh hak untuk mendapatkan dana pensiun.

\section{Konsep Dana Pensiun Syariah.}

Dana pensiun adalah salah satu bentuk badan hukum yang mengelola dan menjalankan program pemanfaatan dana pensiun. Perkembangan dunia asuransi saat ini ditunjukkan dengan semakin berkembanganya transaksi syariah dalam industri keuangan di Indonesia. Dengan demikian, dikembangan pula konsep tentang dana pensiun syariah walaupun perkembangan dana pensiun syariah di Indonesia relatif melambat dibandingkan dengan jenis transaksi keuangan syariah lainnya. Hal ini dikarenakan kurangnya pengetahuan masyarakat tentang manfaat dari dana pensiun syariah itu sendiri.

Berkembangnya pertumbuhan ekonomi Indonesia pada saat ini merupakan suatu era industrial yang menimbulkan pergeseran pola hidup maupun tingkah laku yang mengharapkan kehidupan yang lebih sejahtera, Oleh karena itu, setiap orang tidak hanya memikirkan kehidupan pada saat bekerja tapi juga memikirkan kehidupan setelah pensiun.
Dana pensiun lahir ditengah-tengah berdirinya beberapa lembaga keuangan yang membuat produk dana pensiun secara konvensional. Atas dasar kekhawatiran beberapa orang terutama para ulama tentang dana pensiun konvensional yang dapat berdampak pada munculnya gharar (sesuatu yang tidak jelas) dan maisir (terdapat unsur judi) sehingga para ulama mencari solusi agar masalah gharar dan maisir ini dapat dihindarkan.

Sistem operasional dana pensiun syariah adalah saling bertanggung jawab, bantu-membantu dan saling melindungi antara para pesertanya. (Basuki, 1997)) Lembaga penjamin dana pensiun syariah diberi kepercayaan atau amanah oleh para peserta untuk mengelola premi, mengembangkan dengan jalan yang halal, dan memberikan dana pensiun kepada para peserta sesuai dengan isi akta perjanjian. (Sula, 2004)

Keuntungan lembaga penjamin dana pensiun syariah diperoleh dari pembagian keuntungan dana peserta yang dikembangkan dengan prinsip mudharabah (sistem bagi hasil). Para peserta dana pensiun syariah berkedudukan sebagai shohibul mal (pemilik modal) dan lembaga penjamin dana pensiun syariah berfungsi sebagai 
mudharib (pemegang amanah) (Sula, 2004)

Keuntungan yang diperoleh dari pengembangan dana itu dibagi antara para peserta dan lembaga penjamin dana pensiun syariah sesuai dengan ketentuan yang telah disepakati.

Mekanisme pengelolaan dana peserta (premi) terbagi menjadi dua sistem.

a) Sistem pada produk saving "tabungan"

b) Sistem pada produk non saving "tidak ada tabungan"

Dana pensiun Syariah atau Dana Pensiun Lembaga Keuangan merupakan salah satu jenis dana pensiun sesuai dengan Undang-Undang No. 11 tahun 1992 tentang dana pensiun. Sejauh ini program pensiun syariah di Indonesia masih dilaksanakan secara terbatas oleh DPLK di beberapa bank dan asuransi syariah, salah satu di antaranya adalah Dana Pensiun Bank Muamalat. Umumnya, produk DPLK syariah ini merupakan salah satu produk penghimpunan dana yang ditawarkan oleh bank atau asuransi syariah untuk memberikan jaminan kesejahteraandi hari tua atau di akhir masa jabatan karyawan atau pun nasabahnya.

Prosedur yang dilalui oleh peserta program DPLK syariah, umumnya adalah sebagai berikut: a) Peserta merupakan perorangan atau badan usaha

b) Usia minimal 18 tahun atau telah menikah

c) Mengisi formulir pendaftaran kepesertaan DPLK syariah

d) Iuran bulanan dengan minimum jumlah tertentu, misalnya RP 100.000,-

e) Menyerahkan foto copy kartu identitas diri dan kartu keluarga

f) Membayar biaya pendaftaran

g) Membayar iuran tambahan berupa premi bagi peserta program dana pensiun plus asuransi jiwa

h) Memenuhi semua akad yang ditetapkan oleh DPLK syariah.

Produk dana pensiun yang ditawarkan oleh DPLK syariah menawarkan produk pensiun dengan konsep tabungan dan produk pensiun plus asuransi jiwa. Karakteristik produk dana pensiun dengan konsep tabungan antara lain:

a) Berbentuk setoran tabungan dengan jadwal penarikan diatur dalam ketentuan

b) Selama masa kepesertaan tidak dilindungi oleh asuransi jiwa

c) Manfaat pensiun sebesar total iuran dan hasil investasinya 


\section{Jenis-Jenis Program Dana Pensiun}

Jenis kelembagaan dana pensiun menurut Undang-Undang No. 11 tahun 1992 tentang dana pensiun Pasal 2 bab II dapat digolongkan menjadi dua sebagai berikut:

\section{a. Dana Pensiun Pemberi Kerja (DPPK)}

Dana pensiun pemberi kerja (DPPK) ini adalah unit organisasi dalam suatu perusahaan yang khusus menangani dama pensiun bagi karyawannya. DPPK dibentuk oleh orang atau badan yang memperkerjakan karyawan, untuk menyelenggarakan program pensiun. Pendirian dan penyelenggaraan program pensiun melalui dana pensiun oleh pemberi kerja seifatnya tidak wajib. Akan tetapi, mengingat dampak dan peranan yang positif dari program dana pensiun kepada para karyawan, pemerintah sangat menganjurkan kepada setiap pemberi kerja untuk mendirikan dana pensiun.

b. Dana Pensiun Lembaga Keuangan (DPLK)

Menurut Undang-Undang No. 11 Tahun 1992 pasal 1 butir 4 mengatakan bahwa dana pensiun lembaga keuangan adalah dana pensiun yang dibentuk oleh Bank atau perusahaan asuransi jiwa, untuk menyelnggarakan program pensiun iuran pasti bagi perorangan. Baik karyawan, maupun pekerja mandiri yang terpisah dari dana pensiun pemberi kerja bagi karyawan bank atau perusahaan asuransi yang bersangkutan. Pihak yang diperkenankan untukn mendirikan dana pensiun hanyalah bank umum dan perusahaan asuransi jiwa.

Dana pensiun lembaga keuangan hanya dapat menjalankan program pensiun iuran pasti, program ini terutama diperuntukkan bagi para pekerja mandiri atau perorangan, misalnya dokter, pengacara, pengusaha yang bukan meruapakan karyawan dari lembaga atau orang lain. Biasanya mereka memiliki penghasilan yang bukan berasal dari pemberi kerja tetapi dari usahanya.

Saat ini telah berkembang program dana pensiun individu, seperti Individual Retirement Account (IRA), yang memungkinkan individu, seperti wiraswasta atau lainnya yang secara sukarela merencanakan program pensiunnya. Karena diperuntukkan bagi masa pensiun, tabungan IRA mendapat keringanan pajak. Di Indonesia, program pensiun itu disebut Dana Pensiun Lembaga Keuangan (DPLK). DPLK ini dibentuk oleh badan atau perusahaan asuransi jiwa yang menyelenggarakan program pensiun 
iuran pasti bagi perorangan, baik karyawan maupun pekerja mandiri yang terpisah dari program pensiun pemberi kerja.

Program dana pensiun berdasarkan manfaat dan kontribusinya dikategorikan sebagai program pensiun manfaat pasti (defined-benefit plan) dan program pensiun iuran pasti (defined-contribution plan), dan berdasarkan penyedia jasa provider nya dibedakan menjadi program pensiun pemerintah (public pensiun plan) dan program pensiun swasta (private pensiun plan).

\section{Sistem pada produk Saving (ada unsur tabungan)}

Setiap peserta wajib membayar sejumlah uang (premi) secara teratur kepada lembaga penjamin dana pensiun syariah. Besar premi tergantung kepada keuangan peserta. Akan tetapi, lembaga penjamin dana pensiun syariah menetapkan jumlah minimum premi yang akan dibayarkan. Setiap premi yang dibayarkan oleh peserta akan dipisah dalam dua rekening yang berbeda.

a) Rekening tabungan peserta, ialah dana yang merupakan milik peserta yang bayarkan apabila : perjanjian berakhir, peserta mengundurkan diri, peserta meninggal dunia.

b) Rekening Tabarru', ialah kumpulan dana kebajikan yang telah diniatkan oleh peserta sebagai iuran dana kebajikan untuk tujuan saling menolong, yang dibayarkan apabila : peserta meninggal dunia, perjanjian telah berakhir.

Sistem ini merupakan implementasi dari akad mudharabah dalam pengelolaan dana pensiun syariah, sehingga dana pensiun syariah dapat terhindar dari unsur gharar dan maisir. Selanjutnya dana peserta diinvestasikan sesuai dengan syariat Islam. Tiap keuntungan dari hasil investasi, setelah dikurangi dengan beban asuransi (klaim dari premi asuransi), akan dibagi menurut prinsip mudharabah.

\section{Sistem pada produk Non Saving}

Setiap premi yang dibayarkan peserta, akan dimasukkan ke dalam rekening tabarru' lembaga penjamin dana pensiun syariah, yang merupakan kumpulan dana yang telah diniatkan oleh peserta sebagai iuran dan kebajikan untuk tujuan saling menolong dan saling membantu.

Kumpulan dana peserta ini akan diinvestasikan sesuai dengan syariat Islam. Keuntungan hasil investasi akan dibagi antara peserta dengan lembaga penjamin dana pensiun syariah sesuai dengan prinsip mudharabah. 


\section{Peran Aktuaria Terhadap Sistem}

\section{Dana Pensiun Syariah}

Peran aktuaria terhadap sistem dana pensiun syariah setidaknya mempunyai tiga pokok bagian (Sula, 2004)

\section{a) Sertifikasi Produk}

Perusahaan beroperasi berdasarkan peraturan perundangan di bidang usaha perasuransian yang dikeluarkan oleh pemerintah. Aktuaris akan membuat atau menghitung premi-premi dasar dari produk asuransi syariah/dana pensiun syariah tersebut yang didasarkan pada prinsipprinsip aktuaria.

\section{b) Penaksiran Aktuaria}

Perusahaan asuransi syariah diharuskan membuat laporan tahunan kepada departemen keuangan. Aktuaris melaporkan hasil investigasi aktuaria, yaitu tentang kondisi keuangan asuransi yang layak. Dengan demikian, sebagian dana asuransi syariah dipisahkan untuk membayar manfaat asuransi (cover). Dana ini dikenal sebagai dana cadangan, yaitu untuk pemenuhan kewajiban terhadap perusahaan peserta pada saat terjadi klaim.

\section{c) Aktuaria yang ditunjuk}

Apabila perusahaan dana pensiun syariah tersebut tidak memiliki seorang aktuaris sendiri, maka perusahaan harus menunjuk seorang aktuaris atau suatu lembaga yang diakui oleh departemen keuangan sebagai konsultan aktuaria. Konsultan inilah yang bertanggung jawab untuk memeriksa laporan keuangan yang setiap tahun harus dilaporkan ke departemen keuangan sebagai pihak regulator.

\section{Aspek Aktuaria}

Yang dimaksud dengan aspek aktuaria adalah sejauh mana seorang aktuaris dapat dilibatkan dalam rancangan produk, penentuan rate premi setiap produk, distribusi surplus, valuasi dan tes solvensi, juga aspek-aspek lain dimana keahlian dan kemampuan aktuaris dalam mempergunakan teori probabilitas, statistik, bunga majemuk, dan tingkat investasi yang dipergunakan (Sula, 2004)

\section{Fungsi Dasar Aktuaria}

Fungsi dasar aktuaria merupakan fungsi yang digunakan untuk perhitungan iuran normal dan kewajiban aktuaria. Fungsi dasar aktuaria yang digunakan antara lain fungsi survival komposi, fungsi tingkat bunga, fungsi pendapatan, fungsi 
manfaat dan fungsi anuitas. Berikut ini beberapa penjelasan dari masing-masing fungsi tersebut (Winklevoss, 1992)

\section{a) Fungsi Survival Komposit (Composite Survival Function)}

Fungsi ini menunjukkan peluang peserta sampai waktu diperbolehkan untuk pensiun. Misalkan, jika seorang peserta berusia $x$, maka peluang tetap bekerja selama masa aktif untuk $n$ tahun mendatang dirumuskan sebagai berikut :

$$
{ }_{\mathrm{n}} P_{x}^{(T)}=\frac{l_{x+n}^{(T)}}{l_{x}^{(T)}}
$$

Dengan ${ }_{\mathrm{n}} P_{x}^{(T)}$ adalah peluang seorang peserta berusia $x$ akan tetapi bekerja sampai $n$ tahun mendatang : $l_{x+n}^{(T)}$ adalah jumlah peserta yang masih aktif bekerja pada usia $x+n$ tahun, $l_{x}^{(T)}$ adalah jumlah peserta yang masih bekerja pada usia $x$ tahun.

\section{b) Fungsi Tingkat Bunga}

Fungsi tingkat bunga digunakan untuk mendiskontokan pembayaran masa depan untuj saat ini. Jika $i$ adalah tingkat bunga yang diasumsikan konstan selama $n$ tahun, maka faktor diskonto selama $n$ tahun dihitung sebagai berikut :

$$
V^{n}=\frac{1}{(1+i)^{n}}
$$

Dengan $v^{n}$ adalah faktor diskonto selama $n$ tahun

\section{c) Fungsi Pendapatan}

Pendapatan peserta selama setahun pada usia $x$ dinotasikan dengan $\mathrm{S}_{\mathrm{x}}$, yang merupakan kumpulan pendapatan peserta dari usia masuk $y$ hingga usia $x$-1 sedangkan $\overline{S_{x}}$ merupakan kumulatif pendapatan peserta dari usia masuk $y$ hinga $r$ - 1 yang dirumuskan sebagai berikut :

$$
\overline{S_{x}}=\sum_{t=y}^{r-1} S_{x}
$$

Dengan $S_{x}$ adalah pendapatan peserta selama setahun ketika usia $t$ tahun.

\section{d) Fungsi Manfaat}

Fungsi manfaat digunakan untuk menentukan jumlah manfaat yang dibayarkan kepada peserta pada saat pensiun, pensiun dipercepat, cacat atau kematian. Terdapat tiga jenis fungsi manfaat yang digunakan untuk mendapatkan kumulatif manfaat, yaitu flat dolar unit benefit, career average, dan final average. Pada penelitian ini fungsi manfaat yang digunakan untuk usia pensiun normal adalah career average dengan rumus sebagai berikut :

$$
B_{r}=k S_{r}
$$

Dengan $\mathrm{B}_{\mathrm{r}}$ adalah kumulatif manfaat yang dicapai peserta dari usia $y$ tahun sampai $r-$ $1 ; \mathrm{k}$ adalah proporsi pendapatan rata-rata yang disediakan per tahun masa kerja. 


\section{e) Fungsi Anuitas}

Anuitas adalah suatu pembayaran yang dilakukan dana pensiun kepada peserta dalam jumlah tertentu, yang dilakukan setiap selang waktu atau lama tertentu, secara berkelanjutan. Anuitas dapat diperoleh dengan rumus sebagai berikut :

$$
\ddot{a}_{x}=\sum_{t=0}^{\infty} t P_{x}^{(m)} V^{t}
$$

Dengan $\ddot{a}_{x}$ adalah nilai sekarang dari anuitas seumur hidup pada usia $x, \mathrm{t} P_{x}^{(m)}$ adalah peluang peserta berusia $x$ tahun akan tetap hidup selama $t$ tahun mendatang.

\section{f) Fungsi Iuran}

Iuran adalah suatu besaran yang harus dibayarkan peserta dana pensiun setiap tahun sesuai dengan pendapatan dan proporsi pendapatan yang sudah diakumulasi. Iuran diperoleh dari

$$
{ }_{t}(N C)_{x}=k \cdot S_{r}
$$

dengan

${ }_{t}(N C)_{x}$ adalah iuran normal peserta usia $\mathrm{x}$ hingga $\mathrm{t}$

$k$ adalah proporsi pendapatan

$S_{r}$ adalah fungsi pendapatan

\section{Studi Kasus dan Implementasi}

\section{Fungsi Dasar Aktuaria}

Sebagaimana yang telah dipaparkan pada latar belakang masalah, paper ini menyajikan model dana pensiun untuk para pedagang UMKM, petani, dan nelayan. Beberapa asumsi yang terkait dengan perhitungan dana pensiun akan diapaparkan kemudian.

Akad syariah yang digunakan adalah akad wadiah yang merupakan akad titipan. Artinya, para peserta menitipkan iuran dana pensiun bulanan atau tahunan kepada pengelola, kemudian pengelola diberi hak untuk menginvestasikan dana titipan tersebut sesuai fungsi syariah. Akad ini tidak memberikan bagi hasil bagi pesera atau pengelola sehingga murni titipan.

Selanjutnya, metode yang digunakan adalah metode constant percent of salary, yaitu suatu metode dana pensiun yang iurannya ditetapkan berdasarkan pendapatan peserta per tahun. Akibatnya, dana pensiun yang didapatkan tiap peserta pasti beragam sesuai dengan pendapatannya ketika ia masih berdagang. Usia pensiun ditetapkan yaitu pada usia 55 tahun, dan tidak ada ketentuan usia maksimal untuk bergabung dengan dana pensiun, artinya pedagang yang berusia 54 tahun masih dapat bergabung dan 
mendapatkan dana pensiun di usia 55 tahun. Dalam setahun diasumsikan seorang pedagang efektif berjualan selama 300 hari. Pendapatan proporsional ditentukan sebesar $2 \%$ per tahun.

\section{Contoh:}

Asumsikan seorang pedagang pasar mulai berdagang ketika ia berusia 25 tahun. Pendapatan per hari ia dapat sebesar Rp. 2.000,- . Pendapatan ini mengalami kenaikan sebesar $2 \%$ per tahun. Saat ini ia berusia 55 tahun, artinya sudah saatnya ia menerima dana pensiun. Berapa iuran yang wajib dibayarkan oleh pedagang itu? Berapa dana pensiun yang ia terima setiap tahunnya?

\section{Jawab:}

Lama berdagang $=30$ tahun

Kumulatif pendapatan saat pensiun:

$$
\begin{aligned}
\overline{S_{x}} & =\sum_{y}^{r-1} S_{x} \\
\overline{S_{x}} & =\sum_{25}^{55} S_{x} \\
\overline{S_{x}} & =1240 \cdot(300 \cdot 2000) \\
& =\operatorname{Rp} 744.000 .000,-
\end{aligned}
$$

Manfaat yang diterima per tahun:

$B_{r}=k S_{r}$

$B_{r}=0,02 \cdot(300 \cdot 2000)=\operatorname{Rp~12.000,-~}$ Artinya, setiap bulan ia harus mengeluarkan iuran sebesar Rp. 1.000,-

Tabel di bawah ini menampilkan besaran iuran yang harus dibayarkan oleh pedagang berdasarkan usia mulai berdagang dan rata-rata pendapatan per hari.

Tabel 1. Contoh besaran iuran yang harus dibayarkan peserta setiap bulan

\begin{tabular}{|c|c|r|r|r|r|}
\hline No. & $\begin{array}{r}\text { Usia mulai } \\
\text { berdagang }\end{array}$ & $\begin{array}{r}\text { Rata-rata } \\
\text { pendapatan per } \\
\text { hari (Rp) }\end{array}$ & $\begin{array}{c}\text { Pendapatan } \\
\text { kumulatif (Rp) }\end{array}$ & \multicolumn{1}{c|}{$\begin{array}{c}\text { Manfaat } \\
(\mathrm{Rp})\end{array}$} & $\begin{array}{c}\text { Iuran per bulan } \\
(\mathrm{Rp})\end{array}$ \\
\hline 1 & 25 & 50.000 & 18.600 .000 .000 & 300.000 & 25.000 \\
\hline 2 & 27 & 20.000 & 7.134 .000 .000 & 120.000 & 10.000 \\
\hline 3 & 30 & 5.000 & 1.657 .500 .000 & 30.000 & 1.000 \\
\hline 4 & 32 & 2.000 & 626.000 .000 & 12.000 & 5.000 \\
\hline 5 & 34 & 10.000 & 2.937 .000 .000 & 60.000 & 10.000 \\
\hline 6 & 35 & 20.000 & 5.670 .000 .000 & 120.000 & 25.000 \\
\hline 7 & 40 & 50.000 & 11.400 .000 .000 & 300.000 & 12.500 \\
\hline 8 & 42 & 25.000 & 6.307 .500 .000 & 150.000 & 5.500 \\
\hline 9 & 45 & 15.000 & 2.475 .000 .000 & 90.000 & 50.000 \\
\hline 10 & 50 & 100.000 & 9.450 .000 .000 & 600.000 & \\
\hline
\end{tabular}


Mohamad Andri Ibrahim, Implementasi Metode Constant Percent Of Salary Dalam....

\begin{tabular}{|l|l|r|r|r|r|}
11 & 52 & 75.000 & 4.815 .000 .000 & 450.000 & 37.500 \\
\hline 12 & 54 & 30.000 & 981.000 .000 & 180.000 & 15.000 \\
\hline
\end{tabular}

Dari tabel tersebut, dapat disimpulkan bahwa usia saat mulai berdagang memang berpengaruh pada manfaat yang ia peroleh setiap tahunnya. Akan tetapi, rata-rata pendapatan lebih berpengaruh besar terhadap iuran yang harus dibayarkan oleh peserta setiap bulannya kepada pengelola dana pensiun.

\section{SIMPULAN}

Dana pensiun adalah hak seseorang untuk memperoleh penghasilan setelah bekerja sekian tahun dan sudah memasuki usia pensiun atau ada sebab-sebab lain sesuai dengan perjanjian yang telah ditetapkan. Sedangkan dana pensiun syariah adalah dana pensiun yang dikelola dan dijalankan berdasarkan prinsip syariah.

Jenis kelembagaan dana pensiun menurut Undang-Undang No. 11 Tahun 1992 tentang Dana Pensiun pasal 2 Bab II dapat digolongkan menjadi dua yaitu Dana Pensiun Pemberi Kerja (DPPK) dan Dana Pensiun Lembaga Keuangan (DPLK).

Dari kajian yang telah dipaparkan, maka dapat ditarik beberapa kesimpulan, diantaranya : (1)Usia saat memulai berdagang berpengaruh pada manfaat yang diperoleh setelah pensiun, (2) Rata-rata pendapatan per hari berpengaruh pada iuran yang harus diabayarkan peserta setiap bulan, (3)Iuran yang harus dibayarkan adalah setengah dari rata-rata pendapatan per hari. Oleh karena itu, seharusnya para pedagang tidak merasa keberatan dan terbebani dengan adanya dana pensiun seperti ini. (4)Dana pensiun syariah menjamin kehidupan pedagang UMKM, petani, dan nelayan saat manjalani masa pensiun.

Eksistensi dan keberadaan dana pensiun syariah itu sangat membantu para pelaku UMKM untuk merencanakan hari tua nya oleh sebab itu dengan adanya metode Constant Percent Of Salary ini dapat memfasilitasi para pelaku UMKM mendapatkan jaminan hari tuanya. Dan untuk Lembaga Keuangan Syari'ah program dana pensiun syari'ah untuk para pelaku UMKM merupakan potensi yang sangat besar untuk menyerap dana sehingga selain membantu para pelaku UMKM mendapatkan jaminan tuanya juga dana yang terkumpul dapat di investasikan ke jalan yang halal sehingga perekonomian rakyat dapat berkembang.

\section{DAFTAR PUSTAKA}

Basuki, A. (1997). Konsep dan Operasional Asuransi Takaful Keluarga. Kopkar. AAIJ. 
Elvira, U., \& Linawati, N. (2014). Analisa Hubungan Faktor Demografi Dengan Perencanaan Dana Pendidikan dan Dana Pensiun Pada Masyarakat Ambon. FINESTA 2.2, 29-34.

Emilisa, N. (2001). Hubungan Antara Job Satisfaction Dengan Organizational Commitment Pada Dana Pensiun Lembaga Keuangan Yang Dikelola Oleh Perusahaan Asuransi di Jakarta. Jurnal Media Riset Bisnis \& Manajemen 1.3, 229-244.

Haryanti, A. P. (2013). Pengaruh Orientasi Masa Depan Dan Pengalaman Mengelola Keuangan Terhadap Perencanaan Dana Pensiun Keluarga Di Surabaya. Diss. STIE Perbanas Surabaya.

Meicaecaria, D. R. (2007). PELAKSANAAN PERJANJIAN DANA PENSIUN LEMBAGA KEUANGAN PT. BANK NEGARA INDONESIA (PERSERO) TBK PUSAT DI JAKARTA. program Pascasarjana Universitas Diponegor.

Perry, F. E. (1983). A dictionary of banking. Macdonald and Evans.

Ramadhani, H. (2015). Prospek dan Tantangan Perkembangan Asuransi Syariah di Indonesia. Al-Tijary 1.1, 57-66.

Scott, D. L. (2004). David Scott's Guide to Investing in Mutual Funds. Houghton: Mifflin Harcourt.

Soemitra, A. (2009). Bank dan lembaga keuangan syariah. Jakarta: kencana.

Sula, M. S. (2004). Asuransi Syariah (Life And General) Konsep dan Sistem Operasional. jakarta: Gema Insani.
Sumanto, A. E. (2009). Solusi Berasuransi : Lebih Indah Dengan Syariah. Bandung: Karya Kita.

Veithzal, Rivai., R., \& dkk. (2007). Bank and Financial Institution.

Wahab, Z. (2001). Dana pensiun dan jaminan sosial tenaga kerja di Indonesia. Citra Aditya Bakti.

Winklevoss, H. E. (1992). Pension Mathematics with Numerical Ilustration Pension Reseach Council. Philadelphia: The University of Pennsylvania. 